\title{
Koji srednjoškolci namjeravaju studirati? Pristup visokom obrazovanju i odabir studija
}

Institut za društvena istraživanja u Zagrebu, Zagreb, 2015., 302 str.

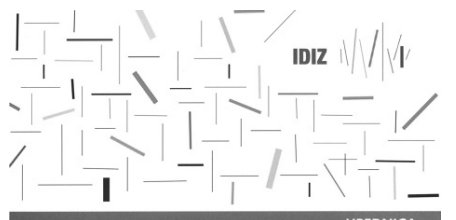

UREDNICA
BRANISLAVA BARANOVIĆ

KOJI SREDNJOŠKOLCI NAMJERAVAJU STUDIRATI? I ODABIR STUDIJA

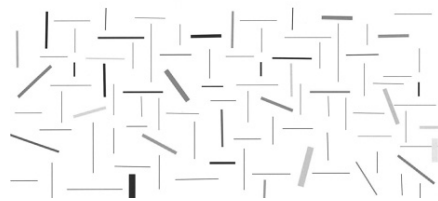
PRISTUP VISOKOM OBRAZOVANU

Interes za istraživanjem visokog obrazovanja povećao se u posljednjem desetljeću budući da se visokoobrazovano stanovništvo smatra preduvjetom ekonomskog i društvenog razvoja zemlje, naglašava urednica zbornika Branislava Baranović. Bez obzira na navedeno, društvene nejednakosti u visokom obrazovanju, kao i na nižim razinama obrazovanja, još uvijek postoje, a ova se knjiga bavi tim problemom i nudi potencijalna rješenja.

Zbornik se sastoji od triju dijelova, odnosno 11 radova, a započinje predgovorom urednice i završava podacima o autorima. Prvi dio zbornika prezentira razvoj visokog obrazovanja u Hrvatskoj, daje pregled literature i teorija o društvenim nejednakostima u obrazovanju i rodnim razlikama u odabiru studija i uspjeha na studiju. Opis i prikaz rezultata samog istraživanja na temelju kojeg je nastao zbornik tema je drugog dijela. Naposljetku, treći dio zbornika okupio je radove na temu javnih politika o društvenim nejednakostima te daje konkretne prijedloge za uklanjanje tih nejednakosti u visokom obrazovanju.

Urednica Branislava Baranović u prvom radu zbornika („Razvoj i socijalna dimenzija visokog obrazovanja u Hrvatskoj“) prikazuje razvoj visokog obrazovanja u Hrvatskoj u razdobljima socijalizma i postsocijalizma te kao najznačajniju promjenu navodi uvođenje bolonjskog sustava, odnosno uvođenje ideje smanjenja društvenih nejednakosti u visokom obrazovanju. No istraživanja pokazuju kako i dalje postoje društvene nejednakosti u visokom obrazovanju te da njima prethode nejednakosti u osnovnoškolskim i srednjoškolskim obrazovnim razinama. Društvene su nejednakosti povezane s obiteljskim porijeklom, ali i vrstom završene srednje škole, odnosno problematizira se državna matura, koja predstavlja dodatnu prepreku upisivanju studija učenicima trogodišnjih strukovnih škola. Autorica također naglašava da su unatoč promjenama u obrazovanju žene u nekim područjima i dalje podzastupljene te zaključuje kako je dioba studija prema spolu dugotrajan problem visokoškolskog obrazovanja u Hrvatskoj (str. 30). 
Temu rodne dimenzije u visokom obrazovanju detaljnije je obradila Ivana Jugović („Teorijsko-empirijski pregled objašnjenja rodnih razlika u obrazovnim odabirima i uspjehu“), a cilj joj je bio odgovoriti zašto se djevojke i mladići razlikuju u obrazovnim odabirima i postignućima kroz pregled teorijskih i empirijskih objašnjenja čimbenika koji bi mogli imati utjecaja na odabir studija i uspjeh na studiju. Navode se biološka objašnjenja, razlike u motivaciji za obrazovno područje, razlike u podršci okoline, nedostatak rodno nestereotipnih uzora, rodni stereotipi u obrazovnim područjima i zanimanjima te nesklad između rodnih uloga i predodžbi u obrazovnim područjima ili zanimanjima kao glavni čimbenici razlike među spolovima u odabiru i uspjehu na studiju. Zaključuje da prijašnja istraživanja najčešće nisu uključivala ulogu stereotipa i rodnih uloga, te se istraživanjima pristupalo u okviru stereotipne muške domene (npr. STEM), a utjecaji šireg društvenog okruženja i obiteljske situacije na odabire i uspjehe u studiju rijetko su istraživani (str. 92). Naglasak je na teorijskom modelu očekivanja i vrijednosti Eccles i suradnika, koji, iako sveobuhvatno pristupa rodnoj dimenziji obrazovnih odabira i postignuća, ne obuhvaća šire društveno okruženje ni obiteljske situacije, za koje se pretpostavlja da imaju veliku ulogu u odabiru studija i obrazovnom uspjehu djevojaka i mladića.

Saša Puzić i Iva Košutić („Sociološki pristupi razumijevanju društvenih nejednakosti u obrazovanju“) pristupili su temi društvenih nejednakosti u obrazovanju koristeći nalaze socioloških teoretičara. Rad nudi pregled obrazovanja kroz funkcionalističke i konfliktne perspektive, referira se na teoriju racionalnog izbora i Boudonovu pozicijsku teoriju te njihove kritike. U fokusu rada Bourdieuova je teorija prakse, koja je bila teorijska osnova istraživanja. Bourdieu je odabran kao referenca jer se bavi pitanjem na koji način pojedinci i grupe koriste razne modele kapitala kako bi unaprijedili svoj položaj u društvu. U radu se daje pregled vrsta kapitala prema Bourdieu te se problematizira prijenos kulturnog kapitala.

Drugi dio knjige započinje radom Branislave Baranović, Karin Doolan, Ivane Jugović, Olgice Klepač, Ive Košutić te Saše Puzića „Teorijske osnove, ciljevi i metodologija istraživanja“, u kojem postavljaju istraživačka pitanja: koje su to društvene karakteristike učenika koje oblikuju njihove odluke o nastavku školovanja, koju ulogu imaju srednje škole te kako su rodne karakteristike i vrijednosti povezane s obrazovnim putem. Teorijski koncept oslanjao se na već prije spomenute teorije, one Bourdieua i Eccles. Provedeno je empirijsko kvantitativno i kvalitativno istraživanje, a neki od rezultata slijede u nastavku.

Iva Košutić, Saša Puzić i Karin Doolan u sljedećem radu, „Društveni i institucionalni aspekti odluke o studiranju i odabira visokoškolske institucije“, s analizom kreću od pretpostavke da učenici koji namjeravaju nastaviti obrazovanje posjeduju više kulturnog, ekonomskog i socijalnog kapitala kao i da procjenjuju svoju srednju školu akademski poticajnom i školom visokog statusa. Dobiveni rezultati u skladu su s teorijom i pretpostavkama. Kao važni akteri u procesu donošenja odluke o studiranju pokazali su se obiteljski i drugi neformalni čimbenici, a nastavnici ili profesionalni savjetnici slabo su povezani s procesom donošenja te odluke. Zanimljivo je da učenici koji planiraju nastaviti školovanje na sveučilišnoj razini posjeduju više kulturnog i ekonomskog kapitala, dok oni koji planiraju nastaviti na veleučilišnoj razini posjeduju više socijalnog kapitala. 
Ivana Jugović u radu „Rodna dimenzija odabira područja studija“ analizirala je razlikuju li se učenici koji biraju različite studije prema konceptima Ecclesine i Bourdieuove teorije. U prijašnjim je istraživanjima fokus bio na objašnjavanju odabira studija djevojaka u stereotipnim muškim zanimanjima i profesijama, a ovo se istraživanje jednako usmjerilo na odabire tipično muških, tehničkih studija i ženskih, društvenohumanističkih. Zaključci istraživanja potvrđuju prethodna, a to je da više od polovice ispitanih učenica planira upisati društveno-humanistički studij te više od polovice učenika namjerava upisati neki od tehničkih studija. ${ }^{1}$ Istraživanje je pokazalo da su rodni stereotipi o zanimanjima vrlo važan čimbenik u odabiru daljnjeg studija, odnosno da je uvjerenje o slabijem talentu vlastite rodne skupine za određeno područje povezano s manjom vjerojatnošću odabira tog područja za studij (str. 182). Zanimljivo je da djevojke koje se odlučuju za tehnički studij slabije prihvaćaju stereotip o većem talentu muškaraca za tehničke znanosti, dok je zabrinjavajući podatak kako ostale skupine ispitanih učenica i učenika prihvaća taj društveno konstruiran i prihvaćen stereotip. Također je iznenađujuće da učenice koje biraju društveno-humanističko područje za daljnje obrazovanje najviše prihvaćaju stereotip da su žene talentiranije za to područje, dok ga učenici odbacuju (str. 176). Rezultati su također pokazali da postoje razlike kod mladića u odabiru stereotipnih muških ili ženskih studija ovisno o njihovom kulturnom kapitalu. Učenici koji planiraju nastaviti obrazovanje na društveno-humanističkim studijima posjeduju veći kulturni kapital, dok oni koji planiraju nastaviti na tehničkom studiju imaju veći ekonomski kapital. Kod djevojaka ne postoji razlika u posjedovanju kulturnog kapitala s obzirom na to koji su studij odabrale, razlika postoji u čitalačkoj praksi.

„Regionalni aspekti odluka o studiranju, distribucija kapitala i namjera studiranja“ rad je Olgice Klepač, čiji je cilj bio ustanoviti postoji li razlika u distribuciji kapitala prema Bourdieuovoj teoriji kojim raspolažu učenici ovisno o regiji iz koje dolaze. Rezultati pokazuju da učenici zagrebačke regije imaju prednost u posjedovanju kulturnih, ekonomskih i socijalnih resursa u odnosu na učenike iz ostalih regija. Najslabije resurse, ali i najmanje izglede obrazovne uspješnosti imaju učenici Sjeverozapadne i Središnje Hrvatske te Slavonije.

Pavel Zgaga započinje treći dio knjige radom „The Social Dimension in the European Higher Education Area". Daje iscrpan pregled bolonjskog procesa te razvoja njegovog koncepta socijalne dimenzije i načina na koji se primjenjuje. Naglašava se uloga studenata u razvijanju bolonjskog procesa budući da su oni ti koji su istaknuli problem pristupa visokom obrazovanju (str. 213). Koncept socijalne dimenzije problematičan je jer nije postojala njegova jasna i nedvosmislena definicija, što ga je činilo podložnim različitim interpretacijama, stoga je 2007. godine službeno definiran te su dogovorene nacionalne strategije za mjerenje i evaluiranje socijalne dimenzije. Nakon što je Europski prostor visokog obrazovanja službeno osnovan, povećao se i broj istraživanja socijalne dimenzije - istraživanja Eurydice i Eurostudent te istraživanja Europske komisije o nejednakosti u obrazovanju. U zaključcima istraživanja ističe se da je potrebno još mnogo rada na napretku socijalne dimenzije,

${ }^{1}$ Analize su provedene samo na uzorku učenika koji planiraju nastaviti školovanje. 
a osim toga pokazala se i potreba za jedinstvenom metodologijom i sustavnim praćenjem napretka. Iako su istraživanja pokazala povećanje broja studenata u visokom obrazovanju, autor zaključuje kako veće sudjelovanje studenata nije obilježje pravednijeg društva s obzirom na to da se povećao broj studenata iz više i srednje klase, ali ne i iz niže klase.

Na rad autora Zgage nadovezuje se i Thomas Farnell („Od empirijskih istraživanja do obrazovne politike: okvir za formuliranje preporuka za socijalnu dimenziju visokog obrazovanja“), koji iznosi konkretne preporuke za obrazovnu politiku u Hrvatskoj pozivajući se na rezultate prijašnjih istraživanja. Autor je kroz faze policy ciklusa dao preporuke međunarodnih dionika za formuliranje politika za socijalnu dimenziju visokog obrazovanja. Smatra kako bi politike vezane za obrazovanje trebale biti kvalitetne i djelotvorne, te se zbog toga moraju donositi na temelju podataka, moraju uključiti stručnjake, ali i javnost te bi trebale biti kontinuirano praćene i evaluirane (str. 240). Daje kritiku obrazovnog sustava u Hrvatskoj, smatra da je društvena nejednakost u našem obrazovnom sustavu vidljiva na svim razinama. Također spominje nisku razinu javnog financiranja obrazovanja, financijske prepreke za pristup obrazovanju i regionalne razlike u kvaliteti škola te stipendiranja na temelju izvrsnosti umjesto na temelju socijalnih kriterija (str. 243). Zaključuje s tabličnim prikazom preporuka konkretnih mjera i intervencija za unapređenje socijalne dimenzije visokog obrazovanja te prikazuje mjere i intervencije iz dokumenata bolonjskog procesa i Europske unije te iz nekih analiza međunarodnih praksi (str. 246).

S obzirom na to da je jedan od fokusa knjige i rodna dimenzija u obrazovanju, Helena Štimac Radin u radu „Pregled javnih politika vezanih uz uspostavu jednakih obrazovnih mogućnosti za žene i muškarce“ nudi preporuke za uklanjanje rodnih stereotipa i nejednakosti u obrazovanju. Započinje pregledom javnih obrazovnih politika u Hrvatskoj, navodi Zakon o ravnopravnosti spolova i Nacionalnu politiku za ravnopravnost spolova kao najvažnije akte koji doprinose unapređenju uvođenja rodno osjetljivog obrazovanja. Ured za ravnopravnost spolova 2008. godine donio je Preporuku o uvođenju kolegija ženskih studija na preddiplomske, diplomske i poslijediplomske studije, a Nacionalno vijeće za znanost 2009. godine donijelo je Pravilnik o znanstvenim i umjetničkim područjima, poljima i granama u koji je uvršteno polje rodnih studija (str. 261-262). Te su akcije otvorile put k institucionaliziranju ženskih studija. Autorica navodi još niz dokumenata koji doprinose uklanjanju stereotipa, no zaključuje kako bez obzira na to još uvijek postoje tradicionalni obrasci ponašanja i stereotipi koji imaju utjecaja na izbor srednjih škola i studija, ali i na nejednak položaj žena i muškaraca na tržištu rada. Nadalje, daje pregled instrumenata kojim se služe Ujedinjeni narodi, Vijeće Europe i Europska unija u borbi protiv rodne nejednakosti i diskriminacije u sferi obrazovanja, kao što su Konvencija o suzbijanju svih oblika diskriminacije žena, Strategija za ravnopravnost spolova te Strategija za ravnopravnost između muškaraca i žena Europske komisije. Iako postoje i primjeri dobre prakse u Hrvatskoj, zaključak je da postoji rodna diskriminacija u obrazovanju koja se preslikava i na tržište rada. Helena Štimac Radin na kraju daje preporuke za uklanjanje rodnih stereotipa te samim time i diskriminacije u obrazovanju. 
Urednica Branislava Baranović u posljednjem se radu („Pristup visokom obrazovanju i preporuke za smanjivanje nejednakosti - zaključna razmatranja“) osvrće se na radove u zborniku te daje svoje preporuke za uklanjanje društvene nejednakosti u visokom obrazovanju: uključivanje i suradnja svih relevantnih aktera i sagledavanje sustava obrazovanja na svim razinama (str. 295), zagovara zadržavanje osmogodišnjeg sustava osnovnoškolskog obrazovanja, reformu srednjoškolskog obrazovanja, naročito programa trogodišnjih strukovnih škola na način da im se olakša pristup visokom obrazovanju. Smatra da bi ulogu nastavnika, profesora i savjetnika trebalo osnažiti kako bi mogli bolje pomoći učenicima u odabiru daljnjeg obrazovanja. Preporučuje fokusiranje na jačanje kulturnog kapitala učenika putem informiranja te se zalaže za nastavak mjera financijske potpore, ali na temelju socijalnih kriterija, a ne kriterija izvrsnosti s obzirom na to da je akademski uspjeh povezan s ekonomskim, kulturnim i ostalim aspektima (str. 296-297).

Ova je knjiga iznimno zanimljivo i vrijedno štivo, preporučljivo osobama svih struka povezanih s obrazovanjem na srednjoškolskoj i visokoškolskoj razini. Pruža iznimno detaljan i iscrpan teorijski pregled, ali i pregled dosadašnjih stranih i domaćih istraživanja. Knjiga se temelji na sveobuhvatnom istraživanju o društvenim nejednakostima u visokoškolskom obrazovanju iz perspektive sociologije i psihologije. Autori daju i konkretne argumentirane prijedloge za uklanjanje društvene nejednakosti u obrazovanju. Također, knjiga otvara i neka nova pitanja te je time stvorila temelj za daljnja istraživanja, i to za stručnjake raznih profila i na svim razinama obrazovanja.

Nadja Čekolj Filozofski fakultet Sveučilišta u Rijeci, Odsjek za pedagogiju 